\title{
Overview on Osteoporosis, Periodontitis and Oral Dysbiosis: The Emerging Role of Oral Microbiota
}

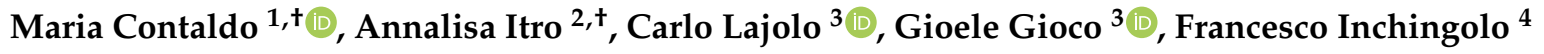 \\ and Rosario Serpico ${ }^{1, *}$ \\ 1 Multidisciplinary Department of Medical-Surgical and Dental Specialties, University of Campania Luigi \\ Vanvitelli, Via Luigi de Crecchio, 6, 80138 Naples, Italy; maria.contaldo@unicampania.it \\ 2 Department of Advanced Medical and Surgical Sciences, University of Campania Luigi Vanvitelli, Via Luigi \\ de Crecchio, 6, 80138 Naples, Italy; annalisa.itro@unicampania.it \\ 3 Head and Neck Department, Fondazione Policlinico Universitario A. Gemelli IRCCS, Roma Università \\ Cattolica del Sacro Cuore, Largo A. Gemelli, 8, 00168 Rome, Italy; carlo.lajolo@unicatt.it (C.L.); \\ gioele.gioco@hotmail.it (G.G.) \\ 4 Department of Interdisciplinary Medicine, University of Bari “Aldo Moro”, Piazza Giulio Cesare 11, \\ 70124 Bari, Italy; francesco.inchingolo@uniba.it \\ * Correspondence: rosario.serpico@unicampania.it; Tel.: +39-0815667674 \\ + These authors should be considered joint first author.
}

Received: 12 August 2020; Accepted: 28 August 2020; Published: 29 August 2020

\begin{abstract}
Osteoporosis (OP) is a bone disease consisting of a progressive loss of bone mineral density (BMD) and therefore resulting in greater susceptibility to fractures. OP shares a number of risk factors and demographic characteristics with periodontitis (PD), a bacteria-induced chronic inflammation of periodontal structures that leads to loss of alveolar bone and teeth. In the last decade, with the advent of gut and oral microbiome studies and profiling, a growing diagnostic and prognostic significance has been attributed to dysbiosis associated with various systemic and organ-specific pathologies. This evidence has inspired research on modulating the microbiota to restore health by the use of prebiotics and probiotics. The aim of this work is to overview the bidirectional interrelationships between $\mathrm{OP}$ and $\mathrm{PD}$, reporting the most recent evidence on triggering factors and, mainly, the role of gut and oral dysbiosis in the onset and progression of both OP and PD, with the perspective in their therapy.
\end{abstract}

Keywords: osteoporosis; periodontitis; oral health; bone and bones/metabolism; microbiome; microbiota; prebiotics; probiotics; mouth diseases; osteology

\section{Introduction}

Numerous systemic conditions and diseases can be associated with or influenced by oral health. From syndromic disorders with oral manifestations [1-4] to systemic diseases with oral involvement [5-7] or oral diseases with extra-oral effects and correlations [8-12], oral health is a condition often related to general well-being.

The present work aimed to overview the bidirectional interrelationships between osteoporosis and oral health, focusing on the new findings from the study of the oral microbiome and on the emerging involvement of oral dysbiosis in the onset of this systemic bone disease.

\section{Osteoporosis}

Osteoporosis (OP) is a common systemic bone disease, in which a generalized and progressive loss of bone mineral density (BMD) increases bone fragility and susceptibility to fracture, which can occur during daily activities or minor trauma $[13,14]$. 
OP is more prevalent among older women (postmenopausal OP), in whom decreased estrogen $[15,16]$ associated with oxidative stress [16,17] is responsible for the loss of BMD [18]; however, it is also reported in men [19] over the age of 65, in association with the use of oral glucocorticoids, androgen deprivation therapy for prostate cancer and various systemic diseases (chronic liver diseases, history of stroke, smoking and alcohol consumption, hyperparathyroidism and/or hyperthyroidism) [20].

OP may be preceded by osteopenia, which is a less severe condition of BMD loss than OP and is associated with a lower risk of bone fractures than in subjects with OP [21].

According to Sozen et al. [22], worldwide, one in three women and one in five men over the age of 50 will suffer an osteoporotic fracture in their lifetime [23], and the most recent reports from the U.S. National Osteoporosis Foundation [24] have confirmed a prevalence 10.2 million Americans over the age of 50 with osteoporosis, and 43.4 million elderly people with low BMD; in Europe, the International Osteoporosis Foundation [25] estimated 22 million women and 5.5 million men with osteoporosis and 3.5 million people with new fragility fractures, while the prevalence of OP in Asian countries ranges from $35.2 \%$ to $25.1 \%$ of elderly women and is considered superior to that of Caucasian women (10.8\%) [26].

\section{Periodontitis}

OP can affect any bone in the body, and, therefore, also the jaws, resulting in cortical thinning increasing with age [27].

Bone thinning and decreased BMD of the jaws are not the only associations between $\mathrm{OP}$ and oral health, but several interrelationships between OP and oral diseases have been reported, mainly with regard to $\mathrm{OP}$ and periodontal disease and $\mathrm{OP}$ and oral dysbiosis.

Among the periodontal diseases, periodontitis (PD) is a bacterially triggered chronic inflammatory condition responsible for the progressive and irreversible destruction and loss of the connective periodontal attachment and alveolar bone resorption, resulting in tooth loss in adults over the age of $50[28,29]$. The etiology of PD is supported by genetic and environmental factors $[30,31]$ and the bacteria responsible for starting the host's inflammatory overreaction have historically been identified as Gram-negative/facultative anaerobic bacteria (mainly Treponema denticola and Porphyromonas gingivalis) that colonize the gingival pocket of predisposed subjects [32]. At this site, the release of a series of proinflammatory cytokines enhances local inflammation which is perpetuated and leads to the progressive destruction of periodontal structures, as the periodontal connective ligaments and the alveolar bones $[15,33]$.

\section{Osteoporosis and Periodontitis}

PD shares many risk factors with OP, such as age, smoking and/or alcohol consumption, body mass index (BMI) and menopause $[34,35]$. Osteoporotic women, in fact, show a greater severity of PD than women without $\mathrm{OP}$, and the two pathologies together considerably affect the quality of life of the subjects [36].

Recently, Xu et al. [37] analyzed the associations between OP and risk of PD using a meta-analysis to establish whether OP is a local indicator of bone loss, or is dependent on or related to the causes of PD: it was found that OP is closely related to the increased risk of developing PD. Furthermore, women with OP present a high risk of developing PD than men and, regardless of gender, patients with OP have a two-fold higher risk of PD [38]. However, the underlying mechanisms still remain undefined [37].

Many hypotheses have arisen to explain how OP can accelerate alveolar bone resorption in PD: (1) the loss of BMD at the level of the alveolar bones could allow for deeper bacterial penetration into the enlarged periodontal space and, in a vicious circle, local inflammation could amplify and accelerate alveolar resorption [27,39]; (2) the overexpression of proinflammatory cytokines with osteoclastic activity is common to both OP and PD [40-42]; (3) some risk factors such as smoking, diabetes, and hormone levels are responsible for both OP and PD [39] (Figure 1). 


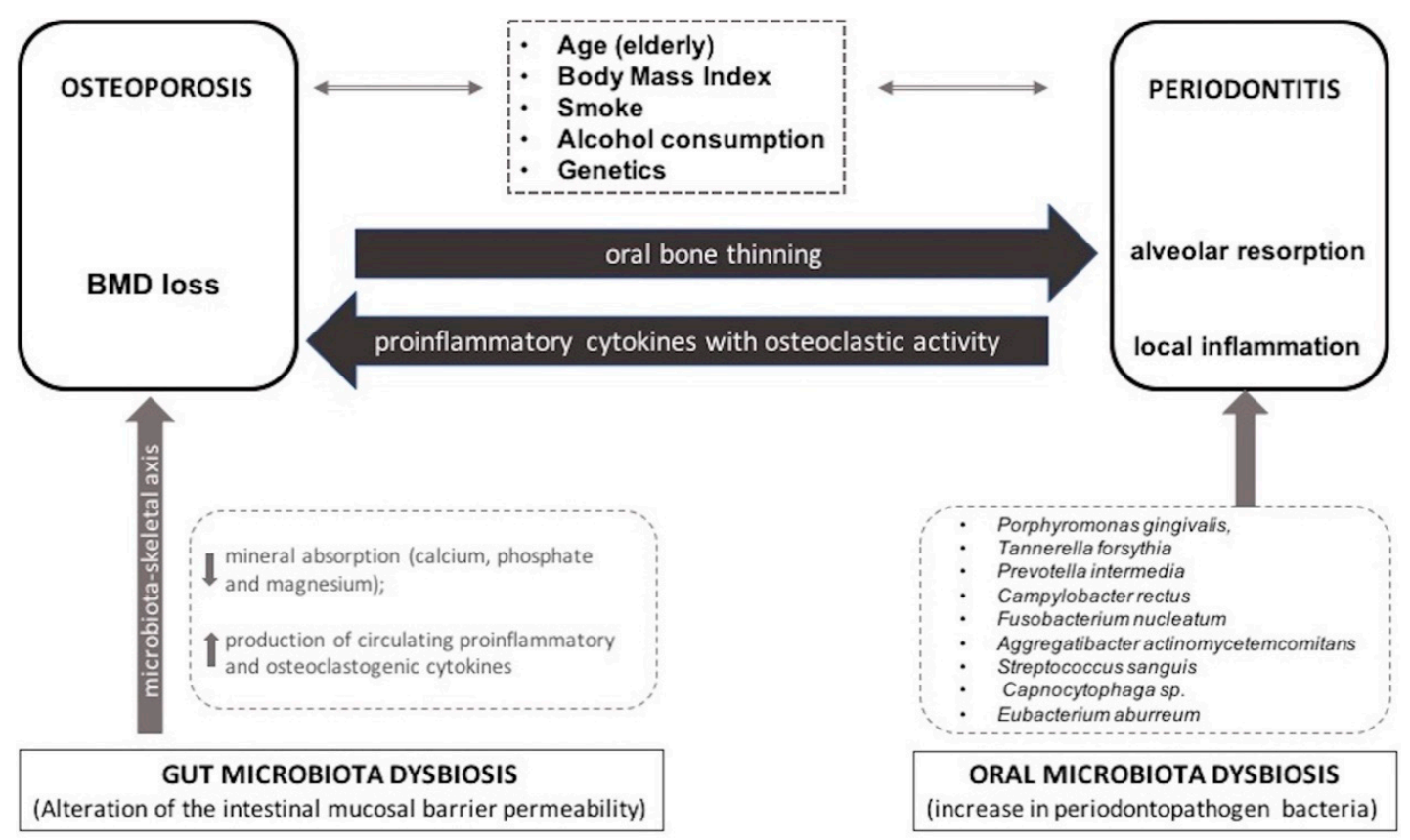

Figure 1. The bidirectional interrelationships between osteoporosis (OP) and periodontitis (PD). They share a series of common risk factors. The bone mineral density (BMD) loss associated with OP may be responsible for increasing the alveolar bone resorption in PD, and, conversely, the local inflammation peculiar of PD may activate systemic osteoclastic cytokines responsible for further BMD decrease. In this scenario, the role of gut and oral dysbiosis may enhance and/ or trigger these events, leading towards a worsening of both pathologies and the healthy state of the affected subjects. BMD, Bone Mineral Density.

\section{Periodontitis and Osteoporosis}

Conversely, other studies have considered that PD and its periodontopathogen bacteria can directly and indirectly promote the onset of $\mathrm{OP}$, which is the chronic inflammatory state responsible for activation of osteoclast not only at the level of oral sites [39], but also elsewhere, as demonstrated in various systemic diseases and conditions triggered and/or aggravated by the presence of PD, such as rheumatoid arthritis [43], cardiovascular diseases [11,44,45], and neurodegenerative diseases such as Parkinson's [46] and Alzheimer's disease [47,48].

\section{Microbiome, Dysbiosis and Osteoporosis}

In recent years, a few more pieces to the puzzle of the association between OP and oral health have been added from studies on the microbiome and its relationship to bone metabolism: after the completion of the mapping of the human genome to sequence and identification of all human genes [49], research has begun to focus on mapping the human microbiome and the related microbiota [50]. By definition, the human microbiota is the collection of all the microorganisms, including eukaryotes, archaea, bacteria and viruses, living in association with the human body in specific ecological niches, while the term "microbiome" refers to all of their genetic material [51-53].

The richest and most studied human niche is the gut environment, which accounts for $95 \%$ of all microorganisms present on and in the human body, but other environments have also been identified, such as nose, eyes, stomach, genitalia, skin and mouth [54].

The findings of differences in oral bacterial composition in unhealthy states, also known as oral dysbiosis, have increasingly opened up new scenarios in the study of the mechanisms underlying OP.

The first research on the human oral microbiome was published in 2010 [55], and, among the over 600 species identified with cultural and non-cultural techniques, 169 seem to be indigenous of the oral cavity (the so-called "core oral microbiome"), arranged, in physiological conditions, in quantity and 
quality in three different ecological niches/intraoral habitats, classified as: Group 1, buccal mucosa, keratinized gingiva, and hard palate; Group 2, saliva, tongue, tonsils, and throat (back wall of oropharynx); and Group 3, sub- and supra-gingival plaque [56,57].

\subsection{Gut Microbiome/Microbiota and $O P$}

Recently, Xu et al. [13] identified and characterized a specific change in gut microbiota of OP patients, consisting of an increase of the total amount of intestinal bacteria, with a prevalence of Bacteroidetes over Firmicutes in the OP group, thus reporting a characteristic fingerprint of gut bacteria composition associated with OP (Bacteroidetes, Prevotellaceae family, Ruminococcaceae family, Faecalibacterium genus, and Dialister genus). Additionally, Das et al. found a greater abundance of Actinomyces, Eggerthella and Clostridium Cluster XlVa in OP subjects compared to a control group [23].

The evidence of pathways through the gut microbiota can influence bone metabolism and its homeostasis lead to the hypothesis of a "microbiota-skeletal" axis [58,59] (Figure 1). According to a series of studies, the gut microbiota is capable of:

1. influencing the absorption of mineral (calcium, phosphate and magnesium) [60];

2. interfering with the immune system (through the production of proinflammatory and osteoclastogenic circulating cytokines that can guide bone resorption in inflammatory conditions [23,60];

3. regulating the synthesis of serotonin and other neurotransmitters involved in bone metabolism $[58,59]$.

Furthermore, in a state of dysbiosis, the intestinal mucosal barrier is more permeable and the abundance of the bacterial endotoxin lipopolysaccharide (LPS) easily increases in serum as well, favoring endotoxemia and osteoclastic activity, thus negatively affecting BMD [58,59].

\subsection{Oral Microbiome/Microbiota and $O P$}

One of the first investigations about the correlation between oral bacteria and $\mathrm{OP}$ was provided by Liang et al., who, in 2013, reported statistically significant reductions in the oral bacterial lining of the tongue of OP women compared to non-OP women [61].

Five years later, in 2018, Banack et al. [62] published the results of a 15-year prospective cohort study, called "OsteoPerio Study", to explore the risk factors for the development and progression of OP and PD in postmenopausal women and highlight the relationship between oral microbiota and oral and systemic health in postmenopausal women. The OsteoPerio Study results confirmed that: (1) OP women had almost double the risk of oral BMD loss compared to non-OP women; (2) systemic and oral BMD loss was greater in older women; (3) severity of PD was inversely associated with BMD. Furthermore, the same authors found, in PD subjects, a strong positive association between specific oral periodontopathogen bacteria (Porphyromonas gingivalis, Tannerella forsythia, Prevotella intermedia and Campylobacter rectus) and severe oral bone loss. Similarly, Brennan et al. [63] tested the association between the presence of oral bacterial infection and oral bone loss in 1256 postmenopausal women, thus reporting eight subgingival bacterial species were mainly associated with severe oral bone loss: Streptococcus sanguis, Prevotella intermedia, Tannerella forsythensis, Capnocytophaga sp., Eubacterium saburreum, Campylobacter rectus, Porphyromonas gingivalis and Fusobacterium nucleatum. On the contrary, Hernández-Vigueras et al. [27], who also conducted an observational cross-sectional study to profile the oral microbiota of postmenopausal women with and without OP, found that nearly $79 \%$ of the women with PD also suffered OP, but no statistically significant differences were found in the quantity and quality of periodontopathogen bacteria investigated (Fusobacterium nucleatum, Aggregatibacter actinomycetemcomitans, Porphyromonas gingivalis, Campylobacter rectus, and Tannerella forsythia) (Figure 1). 


\section{Discussion}

In recent years, the importance of oral health for general well-being has been increasingly confirmed by scientific evidence, elucidating how oral infections and dysbiosis contribute to the triggering or worsening of various types of systemic diseases.

In light of these findings, it has been shown that periodontal pathogenic bacteria as well as intestinal dysbiosis are also involved in the determinism of BMD loss, actively contributing to the onset and worsening of OP (Figure 1).

This evidence has inspired research on the modulation of the microbiota to restore health by the use of prebiotics and probiotics. In particular, it has been shown that a number of host-indigestible food compounds (prebiotics such as galactooligosaccharide, inulin, and resistant starch) are involved in digestive processes by providing nourishment for healthy gut bacteria and thus promoting mineral absorption by enterocytes [59,64]. Moreover, among the living microorganisms that have a positive effect on bone health by acting at the digestive level and known as "probiotics", Lactobacillus sp. (mainly L. reuteri, L. casei, L. rhamnosus and L. salivarius) and Bifidobacteria, seem to significantly decrease osteoclastogenesis and stop bone resorption $[59,65]$.

Promising results on the use of prebiotics and probiotics have also recently emerged for the restoration of oral dysbiosis $[66,67]$ and as adjunctive therapeutic agents to periodontal treatments [68]. Prebiotics promote the nourishment of beneficial bacteria, thus promoting the restoration of a balanced and healthy oral microbiota [69,70]. For example, Rosier et al. [71] reported the effect of nitrate as prebiotic in modulating the composition of the oral microbiome by significantly reducing periodontopathogen bacteria such as Porphyromonas, Fusobacterium, Leptotrichia and Prevotella. Other studies have also reported the benefits of using probiotics: from the use of Lactobacillus sp. in addition to non-surgical periodontal therapy [72], to its adoption to improve the periodontal conditions [73], it results in a reduction of the need for antibiotics [74] and in safe and effective support to conventional mechanical therapies in the management of PD, with positive effects on both oral health and its systemic consequences [75,76]. Another probiotic commensal widely investigated is Streptococcus sp. and the mechanisms by which it is able to mitigate the periodontopathogen activity of Porphyromonas gingivalis. Hanel et al. [77] addressed the competitive adhesiveness of Streptococci sp. to oral epithelial cells as responsible for reducing the invasiveness of Porphyromonas gingivalis, while Ohshima et al. [78], defined the ability of Streptococcus gordonii to mitigate and modulate the inflammatory signaling triggered by Porphyromonas gingivalis and Ho et al. [79] identified the ability of Streptococcus cristatus to alter the expression of virulent genes of Porphyromonas gingivalis.

On these bases, we can guide dentists to not underestimate the OP problem when facing a postmenopausal woman with or without signs and diagnosis of $\mathrm{PD}$ and encourage deeper study on oral dysbiosis and its rebalancing through the use of food products with appropriate and beneficial bacteria.

Author Contributions: Conceptualization, M.C., A.I. and R.S.; writing—original draft preparation, M.C., A.I., C.L.; writing-review and editing, M.C., G.G., R.S., and F.I. All authors have read and agreed to the published version of the manuscript.

Funding: This research received no external funding.

Conflicts of Interest: The authors declare no conflict of interest.

\section{References}

1. Della Vella, F.; Contaldo, M.; Fucile, R.; Panza, F.; Dibello, V.; Kalemaj, Z.; Ninivaggi, R.; Petruzzi, M.; Serpico, R. ORO-Dental Manifestations in West Syndrome. Curr. Top. Med. Chem. 2019, 19, 2824-2828. [CrossRef] [PubMed]

2. Barillari, M.R.; Karali, M.; Di Iorio, V.; Contaldo, M.; Piccolo, V.; Esposito, M.; Costa, G.; Argenziano, G.; Serpico, R.; Carotenuto, M.; et al. Mild form of Zellweger Spectrum Disorders (ZSD) due to variants in PEX1: Detailed clinical investigation in a 9-years-old female. Mol. Genet. Metab. Rep. 2020, 24, 100615. [CrossRef] [PubMed] 
3. Contaldo, M.; Luzzi, V.; Ierardo, G.; Raimondo, E.; Boccellino, M.; Ferati, K.; Bexheti-Ferati, A.; Inchingolo, F.; Di Domenico, M.; Serpico, R.; et al. Bisphosphonate-related osteonecrosis of the jaws and dental surgery procedures in children and young people with osteogenesis imperfecta: A systematic review. J. Stomatol. Oral Maxillofac. Surg. 2020, 2468. Advance online publication. [CrossRef] [PubMed]

4. De Benedittis, M.; Petruzzi, M.; Favia, G.; Serpico, R. Oro-dental manifestations in Hallopeau-Siemens-type recessive dystrophic epidermolysis bullosa. Clin. Exp. Dermatol. 2004, 29, 128-132. [CrossRef]

5. Pastore, L.; Carroccio, A.; Compilato, D.; Panzarella, V.; Serpico, R.; Lo Muzio, L. Oral manifestations of celiac disease. J. Clin. Gastroenterol. 2008, 42, 224-232. [CrossRef]

6. Pastore, L.; De Benedittis, M.; Petruzzi, M.; Tatò, D.; Napoli, C.; Montagna, M.T.; Catassi, C.; Serpico, R. Importanza dei segni orali nella diagnosi di forme atipiche di malattia celiaca [Importance of oral signs in the diagnosis of atypical forms of celiac disease]. Recenti Progress. Med. 2004, 95, 482-490.

7. Rea, F.; Serpico, R.; Pluvio, R.; Busciolano, M.; Iovene, A.; Femiano, F.; Sessa, G.; Belnome, G. Ipoplasia dello smalto dentario in un gruppo di soggetti celiaci. Correlazioni clinico-epidemiologiche [Dental enamel hypoplasia in a group of celiac disease patients. Clinico-epidemiologic correlations]. Minerva Stomatol. 1997, $46,517-524$.

8. Contaldo, M.; Romano, A.; Mascitti, M.; Fiori, F.; Della Vella, F.; Serpico, R.; Santarelli, A. Association between denture stomatitis, candida species and diabetic status. J. Biol. Regul. Homeost. Agents 2019, 33, 35-41.

9. Paoletti, I.; Fusco, A.; Grimaldi, E.; Perillo, L.; Coretti, L.; Di Domenico, M.; Cozza, V.; Contaldo, M.; Serpico, R.; Guida, A.; et al. Assessment of host defence mechanisms induced by Candida species. Int. J. Immunopathol. Pharmacol. 2013, 26, 663-672. [CrossRef]

10. Togni, L.; Mascitti, M.; Santarelli, A.; Contaldo, M.; Romano, A.; Serpico, R.; Rubini, C. Unusual Conditions Impairing Saliva Secretion: Developmental Anomalies of Salivary Glands. Front. Physiol. 2019, 10, 855. [CrossRef]

11. Carinci, F.; Martinelli, M.; Contaldo, M.; Santoro, R.; Pezzetti, F.; Lauritano, D.; Candotto, V.; Mucchi, D.; Palmieri, A.; Tagliabue, A.; et al. Focus on periodontal disease and development of endocarditis. J. Biol. Regul. Homeost. Agents 2018, 32, 143-147. [PubMed]

12. Della Vella, F.; Lauritano, D.; Lajolo, C.; Lucchese, A.; Di Stasio, D.; Contaldo, M.; Serpico, R.; Petruzzi, M. The pseudolesions of the oral mucosa: Differential diagnosis and related systemic conditions. Appl. Sci. 2019, 9, 2412. [CrossRef]

13. Xu, Z.; Xie, Z.; Sun, J.; Huang, S.; Chen, Y.; Li, C.; Sun, X.; Xia, B.; Tian, L.; Guo, C.; et al. Gut Microbiome Reveals Specific Dysbiosis in Primary Osteoporosis. Front. Cell Infect. Microbiol. 2020, 10, 160. [CrossRef] [PubMed]

14. NIH Consensus Development Panel on Osteoporosis Prevention, Diagnosis, and Therapy. Osteoporosis prevention, diagnosis, and therapy. JAMA 2001, 285, 785-795. [CrossRef] [PubMed]

15. Contaldo, M.; Boccellino, M.; Zannini, G.; Romano, A.; Sciarra, A.; Sacco, A.; Settembre, G.; Coppola, M.; Di Carlo, A.; D'Angelo, L.; et al. Sex Hormones and Inflammation Role in Oral Cancer Progression: A Molecular and Biological Point of View. J. Oncol. 2020, 9587971. [CrossRef]

16. Di Domenico, M.; Pinto, F.; Quagliuolo, L.; Contaldo, M.; Settembre, G.; Romano, A.; Coppola, M.; Ferati, K.; Bexheti-Ferati, A.; Sciarra, A.; et al. The Role of Oxidative Stress and Hormones in Controlling Obesity. Front. Endocrinol. (Lausanne) 2019, 10, 540. [CrossRef] [PubMed]

17. Sardaro, N.; Della Vella, F.; Incalza, M.A.; DI Stasio, D.; Lucchese, A.; Contaldo, M.; Laudadio, C.; Petruzzi, M. Oxidative Stress and Oral Mucosal Diseases: An Overview. In Vivo 2019, 33, 289-296. [CrossRef]

18. Penoni, D.C.; Vettore, M.V.; Torres, S.R.; Farias, M.; Leão, A. An investigation of the bidirectional link between osteoporosis and periodontitis. Arch. Osteoporos. 2019, 14, 94. [CrossRef]

19. Adler, R.A. Update on osteoporosis in men. Best Pr. Res. Clin. Endocrinol. Metab. 2018, 32, $759-772$. [CrossRef]

20. Colón-Emeric, C.S.; Pieper, C.F.; Van Houtven, C.H.; Grubber, J.M.; Lyles, K.W.; Lafleur, J.; Adler, R.A. Limited Osteoporosis Screening Effectiveness Due to Low Treatment Rates in a National Sample of Older Men. Mayo Clin. Proc. 2018, 93, 1749-1759. [CrossRef]

21. Kanis, J.A. Assessment of fracture risk and its application to screening for postmenopausal osteoporosis: Synopsis of a WHO report. WHO Study Group. Osteoporos. Int. 1994, 4, 368-381. [CrossRef]

22. Sözen, T.; Özışık, L.; Başaran, N.Ç. An overview and management of osteoporosis. Eur. J. Rheumatol. 2017, 4, 46-56. [CrossRef] [PubMed] 
23. Das, M.; Cronin, O.; Keohane, D.M.; Cormac, E.M.; Nugent, H.; Nugent, M.; Molloy, C.; O’Toole, P.W.; Shanahan, F.; Molloy, M.G.; et al. Gut microbiota alterations associated with reduced bone mineral density in older adults. Rheumatol. (Oxf. Engl.) 2019, 58, 2295-2304. [CrossRef] [PubMed]

24. Wright, N.C.; Looker, A.C.; Saag, K.G.; Curtis, J.R.; Delzell, E.S.; Randall, S.; Dawson-Hughes, B. The recent prevalence of osteoporosis and low bone mass in the United States based on bone mineral density at the femoral neck or lumbar spine. J. Bone Miner. Res. 2014, 29, 2520-2526. [CrossRef] [PubMed]

25. Hernlund, E.; Svedbom, A.; Ivergård, M.; Compston, J.; Cooper, C.; Stenmark, J.; McCloskey, E.V.; Jönsson, B.; Kanis, J.A. Osteoporosis in the European Union: Medical management, epidemiology and economic burden: A report prepared in collaboration with the International Osteoporosis Foundation (IOF) and the European Federation of Pharmaceutical Industry Associations (EFPIA). Arch. Osteoporos. 2013, 8, 136. [CrossRef]

26. Thambiah, S.C.; Yeap, S.S. Osteoporosis in South-East Asian Countries. Clin. Biochem. Rev. 2020, 41, $29-40$. [CrossRef]

27. Hernández-Vigueras, S.; Martínez-Garriga, B.; Sánchez, M.C.; Sanz, M.; Estrugo-Devesa, A.; Vinuesa, T.; López-López, J.; Viñas, M. Oral Microbiota, Periodontal Status, and Osteoporosis in Postmenopausal Females. J. Periodontol. 2016, 87, 124-133. [CrossRef]

28. Slot, D.E.; Valkenburg, C.; Van der Weijden, G. Mechanical plaque removal of periodontal maintenance patients: A systematic review and network meta-analysis. J. Clin. Periodontol. 2020, 47, 107-124. [CrossRef]

29. Wang, C.J.; McCauley, L.K. Osteoporosis and Periodontitis. Curr. Osteoporos. Rep. 2016, 14, $284-291$. [CrossRef]

30. Mombelli, A. Microbial colonization of the periodontal pocket and its significance for periodontal therapy. J. Periodontol. 2000, 76, 85-96. [CrossRef]

31. Hienz, S.A.; Paliwal, S.; Ivanovski, S. Mechanisms of Bone Resorption in Periodontitis. J. Immunol. Res. 2015, 615486. [CrossRef]

32. Loesche, W.J. Microbiology of Dental Decay and Periodontal Disease. In Medical Microbiology, 4th ed.; Baron, S., Ed.; University of Texas Medical Branch: Galveston Galveston, TX, USA, 1996; Chapter 99.

33. Ballini, A.; Cantore, S.; Farronato, D.; Cirulli, N.; Inchingolo, F.; Papa, F.; Malcangi, G.; Inchingolo, A.D.; Dipalma, G.; Sardaro, N.; et al. Periodontal disease and bone pathogenesis: The crosstalk between cytokines and porphyromonas gingivalis. J. Biol. Regul. Homeost. Agents 2015, 29, 273-281. [PubMed]

34. Gera, I. Az osteoporosis mint a destruktív fogágybetegség egyik rizikótényezóje (irodalmi áttekintés) [Osteoporosis: A risk factor for periodontal disease (literature review)]. Fogorv. Szle. 2002, 95, 49-54.

35. Lauritano, D.; Moreo, G.; Carinci, F.; Borgia, R.; Lucchese, A.; Contaldo, M.; Della Vella, F.; Bernardelli, P.; Moreo, G.; Petruzzi, M. Aging and Oral Care: An Observational Study of Characteristics and Prevalence of Oral Diseases in an Italian Cohort. Int. J. Environ. Res. Public Health 2019, 16, 3763. [CrossRef] [PubMed]

36. Pepelassi, E.; Nicopoulou-Karayianni, K.; Archontopoulou, A.D.; Mitsea, A.; Kavadella, A.; Tsiklakis, K.; Vrotsos, I.; Devlin, H.; Horner, K. The relationship between osteoporosis and periodontitis in women aged 45-70 years. Oral Dis. 2012, 18, 353-359. [CrossRef] [PubMed]

37. Xu, S.; Zhang, G.; Guo, J.F.; Tan, Y.H. Associations between Osteoporosis and risk of Periodontitis: A Pooled Analysis of Observational Studies. Oral Dis. 2020. Advance online publication. [CrossRef]

38. Manjunath, S.H.; Rakhewar, P.; Nahar, P.; Tambe, V.; Gabhane, M.; Kharde, A. Evaluation of the Prevalence and Severity of Periodontal Diseases between Osteoporotic and Nonosteoporotic Subjects: A Cross-sectional Comparative Study. J. Contemp. Dent. Pr. 2019, 20, 1223-1228. [CrossRef]

39. Barbato, L.; Francioni, E.; Bianchi, M.; Mascitelli, E.; Marco, L.B.; Tonelli, D.P. Periodontitis and bone metabolism. Clin. Cases Miner. Bone Metab. 2015, 12, 174-177. [CrossRef]

40. Lerner, U.H. Inflammation-induced bone remodeling in periodontal disease and the influence of post-menopausal osteoporosis. J. Dent. Res. 2006, 85, 596-607. [CrossRef]

41. Cantore, S.; Mirgaldi, R.; Ballini, A.; Coscia, M.F.; Scacco, S.; Papa, F.; Inchingolo, F.; Dipalma, G.; De Vito, D. Cytokine gene polymorphisms associate with microbiogical agents in periodontal disease: Our experience. Int. J. Med. Sci. 2014, 11, 674-679. [CrossRef]

42. Inchingolo, F.; Martelli, F.S.; Gargiulo Isacco, C.; Borsani, E.; Cantore, S.; Corcioli, F.; Boddi, A.; Nguyễn, K.; De Vito, D.; Aityan, S.K.; et al. Chronic Periodontitis and Immunity, Towards the Implementation of a Personalized Medicine: A Translational Research on Gene Single Nucleotide Polymorphisms (SNPs) Linked to Chronic Oral Dysbiosis in 96 Caucasian Patients. Biomedicines 2020, 8, 115. [CrossRef] [PubMed] 
43. Potempa, J.; Mydel, P.; Koziel, J. The case for periodontitis in the pathogenesis of rheumatoid arthritis. Nat. Rev. Rheumatol. 2017, 13, 606-620. [CrossRef] [PubMed]

44. Rydén, L.; Buhlin, K.; Ekstrand, E.; de Faire, U.; Gustafsson, A.; Holmer, J.; Kjellström, B.; Lindahl, B.; Norhammar, A.; Nygren, Å.; et al. Periodontitis Increases the Risk of a First Myocardial Infarction: A Report From the PAROKRANK Study. Circulation 2016, 133, 576-583. [CrossRef] [PubMed]

45. Holmstrup, P.; Damgaard, C.; Olsen, I.; Klinge, B.; Flyvbjerg, A.; Nielsen, C.H.; Hansen, P.R. Comorbidity of periodontal disease: Two sides of the same coin? An introduction for the clinician. J. Oral. Microbiol. 2017, 9, 1332710. [CrossRef] [PubMed]

46. Dominy, S.S.; Lynch, C.; Ermini, F.; Benedyk, M.; Marczyk, A.; Konradi, A.; Nguyen, M.; Haditsch, U.; Raha, D.; Griffin, C.; et al. Porphyromonas gingivalis in Alzheimer's disease brains: Evidence for disease causation and treatment with small-molecule inhibitors. Sci. Adv. 2019, 5, eaau3333. [CrossRef] [PubMed]

47. Singhrao, S.K.; Olsen, I. Assessing the role of Porphyromonas gingivalis in periodontitis to determine a causative relationship with Alzheimer's disease. J. Oral Microbiol. 2019, 11, 1563405. [CrossRef]

48. Pritchard, A.B.; Crean, S.; Olsen, I.; Singhrao, S.K. Periodontitis, Microbiomes and their Role in Alzheimer's Disease. Front. Aging NeuroSci. 2017, 9, 336. [CrossRef] [PubMed]

49. Collins, A. Mapping in the sequencing era. Hum. Hered. 2000, 50, 76-84. [CrossRef]

50. Lederberg, J.; McCray, A.T. 'Ome Sweet' Omics-A Genealogical Treasury of Words Genealogical Treasury of Words. Scientist 2001, 15, 8.

51. Human Microbiome Project Consortium. Structure, function and diversity of the healthy human microbiome. Nature 2012, 486, 207-214. [CrossRef]

52. Nature.com: Microbiome. Available online: https://www.nature.com/subjects/microbiome. (accessed on 28 July 2020).

53. Berg, G.; Rybakova, D.; Fischer, D.; Cernava, T.; Vergès, M.C.; Charles, T.; Chen, X.; Cocolin, L.; Eversole, K.; Corral, G.H.; et al. Microbiome definition re-visited: Old concepts and new challenges. Microbiome 2020, 8, 103. [CrossRef] [PubMed]

54. Baquero, F.; Nombela, C. The microbiome as a human organ. Clin. Microbiol. Infect. 2012, 18, 2-4. [CrossRef] [PubMed]

55. Dewhirst, F.E.; Chen, T.; Izard, J.; Paster, B.J.; Tanner, A.C.; Yu, W.H.; Lakshmanan, A.; Wade, W.G. The human oral microbiome. J. Bacteriol. 2010, 192, 5002-5017. [CrossRef]

56. Segata, N.; Haake, S.K.; Mannon, P.; Lemon, K.P.; Waldron, L.; Gevers, D.; Huttenhower, C.; Izard, J. Composition of the adult digestive tract bacterial microbiome based on seven mouth surfaces, tonsils, throat and stool samples. Genome Biol. 2012, 13, R42. [CrossRef] [PubMed]

57. Wade, W.G.; Prosdocimi, E.M. Profiling of Oral Bacterial Communities. J. Dent. Res. 2020, 99, $621-629$. [CrossRef]

58. Behera, J.; Ison, J.; Tyagi, S.C.; Tyagi, N. The role of gut microbiota in bone homeostasis. Bone 2020, 135, 115317. [CrossRef]

59. Chen, Y.C.; Greenbaum, J.; Shen, H.; Deng, H.W. Association Between Gut Microbiota and Bone Health: Potential Mechanisms and Prospective. J. Clin. Endocrinol. Metab. 2017, 102, 3635-3646. [CrossRef]

60. Gargiulo Isacco, C.; Ballini, A.; Paduanelli, G.; Inchingolo, A.D.; Nguyen, K.; Inchingolo, A.M.; Pham, V.H.; Aityan, S.K.; Schiffman, M.; Tran, T.C.; et al. Bone decay and beyond: How can we approach it better. J. Biol. Regul. Homeost. Agents 2019, 33, 143-154.

61. Liang, W.; Li, X.; Li, Y.; Li, C.; Gao, B.; Gan, H.; Li, S.; Shen, J.; Kang, J.; Ding, S.; et al. Tongue coating microbiome regulates the changes in tongue texture and coating in patients with post-menopausal osteoporosis of Gan-shen deficiency syndrome type. Int. J. Mol. Med. 2013, 32, 1069-1076. [CrossRef]

62. Banack, H.R.; Genco, R.J.; LaMonte, M.J.; Millen, A.E.; Buck, M.J.; Sun, Y.; Andrews, C.A.; Hovey, K.M.; Tsompana, M.; McSkimming, D.I.; et al. Cohort profile: The Buffalo OsteoPerio microbiome prospective cohort study. BMJ Open 2018, 8, e024263. [CrossRef]

63. Brennan, R.M.; Genco, R.J.; Wilding, G.E.; Hovey, K.M.; Trevisan, M.; Wactawski-Wende, J. Bacterial species in subgingival plaque and oral bone loss in postmenopausal women. J. Periodontol. 2007, 78, 1051-1061. [CrossRef] [PubMed]

64. Rizzoli, R. Nutritional influence on bone: Role of gut microbiota. Aging Clin. Exp. Res. 2019, 31, 743-751. [CrossRef] 
65. Morato-Martínez, M.; López-Plaza, B.; Santurino, C.; Palma-Milla, S.; Gómez-Candela, C. A Dairy Product to Reconstitute Enriched with Bioactive Nutrients Stops Bone Loss in High-Risk Menopausal Women without Pharmacological Treatment. Nutrients 2020, 12, 2203. [CrossRef] [PubMed]

66. Zaura, E.; Twetman, S. Critical Appraisal of Oral Pre- and Probiotics for Caries Prevention and Care. Caries Res. 2019, 53, 514-526. [CrossRef] [PubMed]

67. Nguyen, T.; Brody, H.; Lin, G.H.; Rangé, H.; Kuraji, R.; Ye, C.; Kamarajan, P.; Radaic, A.; Gao, L.; Kapila, Y. Probiotics, including nisin-based probiotics, improve clinical and microbial outcomes relevant to oral and systemic diseases. J. Periodontol. 2000 2020, 82, 173-185. [CrossRef] [PubMed]

68. Huck, O.; Mulhall, H.; Rubin, G.; Kizelnik, Z.; Iyer, R.; Perpich, J.D.; Haque, N.; Cani, P.D.; de Vos, W.M.; Amar, S. Akkermansia muciniphila reduces Porphyromonas gingivalis-induced inflammation and periodontal bone destruction. J. Clin. Periodontol. 2020, 47, 202-212. [CrossRef]

69. Slomka, V.; Hernandez-Sanabria, E.; Herrero, E.R.; Zaidel, L.; Bernaerts, K.; Boon, N.; Quirynen, M.; Teughels, W. Nutritional stimulation of commensal oral bacteria suppresses pathogens: The prebiotic concept. J. Clin. Periodontol. 2017, 44, 344-352. [CrossRef]

70. Hirasawa, M.; Kurita-Ochia, T. Probiotic Potential of Lactobacilli Isolated from Saliva of Periodontally Healthy Individuals. Oral Health Prev. Dent. 2020, 18, 563-570. [CrossRef]

71. Rosier, B.T.; Buetas, E.; Moya-Gonzalvez, E.M.; Artacho, A.; Mira, A. Nitrate as a potential prebiotic for the oral microbiome. Sci. Rep. 2020, 10, 12895. [CrossRef]

72. Pudgar, P.; Povšič, K.; Čuk, K.; Seme, K.; Petelin, M.; Gašperšič, R. Probiotic strains of Lactobacillus brevis and Lactobacillus plantarum as adjunct to non-surgical periodontal therapy: 3-month results of a randomized controlled clinical trial. Clin. Oral Investig. 2020. Advance online publication. [CrossRef]

73. Cantore, S.; Ballini, A.; De Vito, D.; Abbinante, A.; Altini, V.; Dipalma, G.; Inchingolo, F.; Saini, R. Clinical results of improvement in periodontal condition by administration of oral probiotics. J. Biol. Regul. Homeost. Agents 2018, 32, 1329-1334.

74. Inchingolo, F.; Dipalma, G.; Cirulli, N.; Cantore, S.; Saini, R.S.; Altini, V.; Santacroce, L.; Ballini, A.; Saini, R. Microbiological results of improvement in periodontal condition by administration of oral probiotics. J. Biol. Regul. Homeost. Agents 2018, 32, 1323-1328. [PubMed]

75. Matsubara, V.H.; Bandara, H.M.; Ishikawa, K.H.; Mayer, M.P.; Samaranayake, L.P. The role of probiotic bacteria in managing periodontal disease: A systematic review. Expert Rev. Anti-Infect. Ther. 2016, 14, 643-655. [CrossRef] [PubMed]

76. Bustamante, M.; Oomah, B.D.; Mosi-Roa, Y.; Rubilar, M.; Burgos-Díaz, C. Probiotics as an Adjunct Therapy for the Treatment of Halitosis, Dental Caries and Periodontitis. Probiotics Antimicrob. Proteins 2020, 12, 325-334. [CrossRef] [PubMed]

77. Hanel, A.N.; Herzog, H.M.; James, M.G.; Cuadra, G.A. Effects of Oral Commensal Streptococci on Porphyromonas gingivalis Invasion into Oral Epithelial Cells. Dent. J. (Basel) 2020, 8, 39. [CrossRef] [PubMed]

78. Ohshima, J.; Wang, Q.; Fitzsimonds, Z.R.; Miller, D.P.; Sztukowska, M.N.; Jung, Y.J.; Hayashi, M.; Whiteley, M.; Lamont, R.J. Streptococcus gordonii programs epithelial cells to resist ZEB2 induction by Porphyromonas gingivalis. Proc. Natl. Acad. Sci. USA 2019, 116, 8544-8553. [CrossRef]

79. Ho, M.H.; Lamont, R.J.; Xie, H. Identification of Streptococcus cristatus peptides that repress expression of virulence genes in Porphyromonas gingivalis. Sci. Rep. 2017, 7, 1413. [CrossRef]

(C) 2020 by the authors. Licensee MDPI, Basel, Switzerland. This article is an open access article distributed under the terms and conditions of the Creative Commons Attribution (CC BY) license (http://creativecommons.org/licenses/by/4.0/). 